glyoxylic and other tryptophane tests were positive. In freshly prepared samples the ninhydrin test was negative, but samples which had been kept in solution at room temperature for several days and which rapidly lost activity readily gave this test. Samples hydrolysed by either acid or alkali gave a vivid colour with ninhydrin (deep purple slowly fading to cherry red). The Molisch test for carbohydrate was strongly positive and was typical of that of 'bound' carbohydrate, in which the Molisch colour develops relatively slowly but remains stable for periods up to several hours. After hydrolysis, products were obtained which reduced Fehling's solution weakly and gave a positive Elson-Morgan test for aminosugar. X-ray powder photographs, kindly taken by Drs. F. J. Llewellyn and A. D. Booth of our X-ray department, of all crystalline samples showed a number of diffuse rings in which there was no evidence of a highly ordered structure. The photographs were similar to those of erystalline pepsin taken at the same time and to those of some crystalline 'globular' proteins as described by Astbury ${ }^{11}$.

The yield of choline-esterase calculated on the amounts estimated in the original serum gave surprisingly high figures, usually between 60 and 100 per cent but often much higher. We interpret this result as being due to the existence in serum of one or more powerful inhibitors which were removed during the purification process. The figures representing activities are usually taken as an indication of the degree of purification. We prefer, however, to postpone the interpretation of the significanee of these figures until further information is available on the abovementioned inhibitor, and on possible activators removed during the purification process.

We do not attempt at this stage to claim that the crystalline mucoprotein is indeed the pure enzyme, but the absence in the preparation of heatcoagulable albumins and globulins, the steady and regular increase in activity per dry weight during the process of purification and the initial negative ninhydrin test make it appear probable that the choline-esterase activity is intimately connected with the mucoprotein. It appears, moreover, to be the first mucoprotein which has been separated from the albumins and globulins of serum by a method which avoids the use of substances (such as alcohol) or procedures (for example, heat) known to denature or to destroy enzymès, in particular choline-esterase. Mucoproteins, having varying amounts of carbohydrate residue, have frequently been prepared from serum after removal of albumins and globulins by coagulation methods involving the use of heat and alcohol (for literature see Rimington ${ }^{\mathbf{1 2}}$ ). Our preparation had some properties similar to those of seromucoid $^{12}$, but the method of preparing this mucoprotein would, of course, destroy choline-esterase aetivity.

Since this work was completed, there has appeared a paper ${ }^{13}$ on "pseudo-choline-esterase" which the author has isolated in $\mathbf{5}$ per cent yield from horse serum and which is claimed to have an activity $\mathbf{5 , 0 0 0}$ times that of serum. The reason for the big discrepancy between this apparent high activity and our own is not immediately clear. In view of the fact that despite experimental losses our yields are so consistently high, we are inclined to the view that the divergence lies in the method ${ }^{14}$ of assay of the enzymic activity; particularly since we have preferred not to use any enzyme stabilizer (gum acacia) and have worked with low'er substrate concentrations.
I Loewi, O., and Navtril, E., Pflug. Arch., 214, 678, 689 (1926). 2 Stedman, E., Stedman, E., and Easson, L. H., Biochem. J., 26,
2056 (1932).

${ }^{3}$ Schütz, F., Nature, 148, 725 (1941).

4 Schütz, F., Quart. J. Exp. Physiol., in the Press.

5 Stedman, E., and Stedman, E., Biochem. J., 29, 2563 (1935).

'Schütz, F., Nature, 139, 629 (1937).

${ }^{7}$ Bader, R., and Schütz, F., Trans. Faraday Soc., in the Press.

${ }^{8}$ Hewitt, L. F., Biochem. J., 21, 216 (1927).

Schütz, F., Trans. Faraday Soc., 38, 85 and 94 (1942).

${ }^{10}$ Stacey, M., Chem. and Ind., 62, 110 (1943).

${ }^{11}$ Astbury, W. T., "Textile Fibres Under X-Rays", 46 (I.C.I., Ltd.).

${ }^{12}$ Rimington, C., Biochem. J., 34, 931 (1940).

13 Strelitz, F., Biochem. J., 38, 86 (1944).

14 Schütz, F., J. Physiol., 102, 259 and 269 (1943).

\section{UNIVERSITY DEVELOPMENTS IN GREAT BRITAIN}

$T$ HE Conference on University Developments, arranged by the Association of University Teachers on June 2, at which representatives of twenty universities and colleges were present, considered three of the main topics of the Report on University Developments adopted by the Council of the Association in December and published in the Universities' Review of May. First, Prof. Ray Pascal opened a discussion on university entrance requirements, maintenance grants, curricula and appointments boards. Emphasizing that the consideration of such matters pertaining to the teaching functions of universities could not be conducted without reference to other functions such as research, Prof. Pascal directed attention to two main objects behind the proposals of the Report : the development of people who will make a useful contribution to society in whatever profession they may choose; and the development of individual personality of people able to "distinguish, choose and judge". Too often we have aimed alternately at one or the other. The Council of the Association does not believe that this is either good or necessary. We need not only really efficient experts but also efficiency in the widest sense applied to society as a whole, calling for broad knowledge and understanding, for initiative, adaptability and personality. The proposals to replace the scholarship system by one of maintenance grants, to change the character of the entrance requirements and to adapt the curriculum are all intimately related, and Prof. Pascal noted that related views have been expressed in the report of the Education Committee of the Federation of British Industries.

In regard to maintenance grants, the Association is concerned not only that the best should be provided for, but also that a great number of average good students should be forthcoming. Many scholarships awarded in recent times have denoted not special academic merit, but a recognition of fitness to study, and a change in name to correspond with this fact is proposed and an increase of 50 per cent in such grants-a provisional figure which can be soon attained without extensive new building and for which reserves of university teachers can be found. In regard to entrance requirements, the Association's proposals to correct the bias towards premature specialization centre in the transformation of the higher school certificate into a school-leaving examination in about six subjects, and useful for all leaving purposes, not merely for the universities. For university entrance, a further examination is needed 
in a smaller number of subjects, but so framed as to prevent exclusive concern with two or three subjects over a long period. Here agreement and co-operation between universities rather than uniformity is required.

The Association's criticism of degree courses is that too many students specialize who are not fitted for the most advanced specialist work, and that the best students need a broader basis. It proposes a common course in the first year or two, followed by full specialization for those suited by ability and bent, and extension of the normal university course to four years once the post-war rush is over, with a much larger entry for the general degree course. Again, in regard to appointment boards, these should be bodies on which university teachers meet employing bodies to exchange information and to consult together on the relations between education and employment.

Dr. D. R. Pye, opening a discussion on research, using the word in its widest sense as giving vitality to teaching, pointed out that while it cannot be expected that all members of a university staff will remain productive in research, much good would result from closer association between universities and the research staffs both in Government establishments and in industry, and he referred to the value of university lectures by research workers on their special subjects as a stimulus to post-graduate research groups in the universities. Also it must be possible for the universities to pay salaries which are adequate to retain the men who are capable of effective research and of training recruits in research ; the number of such men must be sufficient to prevent them from being overburdened with teaching.

The closer association of the universities with industry presents special difficulties in the engineering faculties. Here, except in the borderland of physics and engineering, and especially towards the physical side, effective research is difficult to arrange at the universities, and it will always be difficult for the university work to keep in touch with changing technique. Accordingly, Dr. Pye welcomed the encouragement of local contacts with industry. $\mathrm{He}$ deprecated too close inquiry as to whether research is pure or applied: freedom in planning and in execution are pre-requisites for research which is worth while, but a fairly definite goal is no bad thing for the majority.

Prof. S. Brodetsky, opening the third discussion, on salaries, superannuation and representation of academic staff and academic council of the universities, said that a considerable increase in the staffs of universities is clearly necessary as well as a new scale of salaries, but he appeared to be opposed to the establishment of further research fellowships as recommended in the Association's Report. In regard to the new scale of salaries suggested, he emphasized, the desirability of discontinuing the so-called "Grade IV" appointments, and, secondly, that lecturers should reach a reasonable salary by about the age of forty. The Report proposes a salary of $£ 800$ to be reached by annual increments, following a probationary period, at about that age. Higher appointments, such as Grade I lecturers or readers, should similarly rise to $£ 1,100$, non-professorial heads of departments to $£ 1,300$, and for professors a basic salary of $£ 1,500$ is suggested. With regard to superannuation, a special Government grant is called for to put on a reasonable level members of university staffs of long service.
Prof. Brodetsky. also directed attention to the importance of university teachers taking a proper place in the administration of the universities, and to the recommendations in the Association's Report that university councils should include a fair representation of the university staff, both professorial and non-professorial. Each university should have permanent academic committees dealing with the question of development and other problems, while in connexion with regional universities special thought must be given to the place that graduates should occupy in their development and government. Finally, referring to the relations between the universities, he explained the reasons why the Association's Report recommended the establishment of an academic council of the universities to facilitate consultation and the work both of the University Grants Committee and the informal Vice-Chancellors' Committee.

The summer meeting of the Central Council of the Association of University Teachers took place on June 9 and 10 at the University of Birmingham. Forty-five members were present, representing the local associations in the various university institutions of England and Wales. The action of the University of Birmingham in making a gift of $£ 100$ to the University Books for China Fund, following an appeal made by Prof. E. R. Dodds, of the University of Oxford, who had recently returned from a visit to Chinese universities, was brought to the notice of members in the hope that other university institutions might feel able to help in a similar manner. A report was made regarding the conference of representatives of university governing bodies and members of the executive committee of the Association which took place on June 2 (see above). A Conference Committee was appointed to arrange for a series of conferences with, among others, school teachers and professional, technical and industrial organizations, the National Union of Students, etc., to consider specific problems arising out of the report. Copies of a booklet on "Health and the Student", issued by the National Union of Students, were before the meeting and, after consideration, it was agreed that it was desirable to support the efforts of the Union in this direction, and to recommend local branches to raise the whole question of student health (including medical care and welfare, living conditions and recreative facilities) with their governing bodies. The election of officers for the session 1944-45 was proceeded with, Prof. Roy Pascal of the University of Birmingham being appointed president.

\section{A FLATWORM PARASITE OF FRESHWATER TROUT}

$I^{\mathrm{N}}$ NVESTIGATING the cause of the deaths of practically 100 per cent of the freshwater trout in an open storage reservoir in South Wales in 1942, J. B. Duguid and Edith M. Sheppard (J. Path. and Bact., 56, 73; 1944) found that they were due to general peritonitis caused by the plerocercoids of a tapeworm belonging to the family Diphyllobothridæ. Hundreds of these flatworms, 1-10 cm. long, were found burrowing in the peritoneal tissues. The sticklebacks (Gasterosteus aculeatus) in the same reservoir were also infested. 